\title{
Ichthyoplankton in the Nacional Natural Park Isla Gorgona (Pacific Ocean of Colombia) during September 2005
}

\author{
Eugenia Escarria ${ }^{1}$, Beatriz S. Beltrán-León ${ }^{2}$, Alan Giraldo ${ }^{1,3}$ \& Fernando Zapata ${ }^{1}$ \\ ${ }^{1}$ Universidad del Valle, Departamento de Biología \\ Grupo de Investigación en Ecología Arrecifes Coralinos, A.A. 25360, Cali, Colombia \\ ${ }^{2}$ Ministerio de Ambiente, Vivienda y Desarrollo Territorial, \\ Unidad Administrativa Especial del Sistema de Parques Nacionales Naturales \\ Dirección Territorial Sur Occidente, Cali, Colombia \\ ${ }^{3}$ Universidad del Valle, Departamento de Biología \\ Grupo de Investigación en Ecología Animal, A.A. 25360, Cali, Colombia
}

\begin{abstract}
The taxonomy, spatial distribution, and abundance patterns of ichthyoplankton collected in September 2005 from the coastal zone of Gorgona Island National Natural Park in the Colombian Pacific Ocean were analyzed. The ichthyoplankton in the study area was collected with oblique tows using a minibongo net (30 cm; $250 \mu \mathrm{m} \mathrm{mesh).}$ The tows were made from variable depths depending on the stations but never exceeding $50 \mathrm{~m}$. A sampling grid with 24 stations was used. Fish larvae abundance was between 69 and 16,837 larvae $1000 \mathrm{~m}^{-3}$. Larval stages of 35 species belonging to 14 families were identified. Gobiidae (35\%) and Sciaenidae (15\%) were the most abundant and frequent families. Lythrypnus sp. (8,519 larvae $\left.1000 \mathrm{~m}^{-3}\right)$ and Sciaenidae spp. $\left(6,553\right.$ larvae $\left.1000 \mathrm{~m}^{-3}\right)$ were the most abundant and frequent species. The analysis of larval spatial distribution suggested a tendency to aggregate towards the south of the study zone, approximately $5 \mathrm{~km}$ offshore. Significant differences were detected in the ichthyoplankton abundances between the eastern and the western zones of the study area (Mann-Whitney, $\mathrm{p}=0.000062$ ). However, no significant relationship was observed between ichthyoplankton abundance and average temperature (Spearman, $\mathrm{R}=-0.346$ ), salinity (Spearman, $\mathrm{R}=0.227$ ), and water transparency (Spearman, $\mathrm{R}=0.10$ ).
\end{abstract}

Key words: fish larvae, taxonomy, spatial distribution, Gorgona Island, Colombia.

\section{Ictioplancton en el Parque Nacional Natural Isla Gorgona (Océano Pacífico colombiano) durante septiembre 2005}

\begin{abstract}
RESUMEN. Se presentan los resultados del análisis taxonómico, el patrón de distribución espacial y abundancia del ictioplancton colectado en septiembre 2005, en la zona de influencia costera del Parque Nacional Natural isla Gorgona, Océano Pacífico colombiano. El ictioplancton en la zona de estudio se obtuvo a partir de arrastres oblicuos con una red minibongo ( $30 \mathrm{~cm}$ diámetro y abertura de malla de $250 \mu \mathrm{m}$ ), desde una profundidad variable dependiente a la profundidad de la estación, pero no mayor a $50 \mathrm{~m}$, siguiendo una grilla de muestreo de 24 estaciones. La abundancia de larvas en la zona de estudio estuvo entre 69 y 16.837 larvas $1000 \mathrm{~m}^{-3}$. Se identificaron estadios larvales de 35 especies pertenecientes a 14 familias, entre las que destacó por su abundancia y frecuencia de ocurrencia las familias Gobiidae (35\%) y Sciaenidae (15\%). Las especies más abundantes y con mayor ocurrencia fueron Lythrypnus sp. (8.519 larvas $1000 \mathrm{~m}^{-3}$ ) y Sciaenidae spp. (6.553 larvas $\left.1000 \mathrm{~m}^{-3}\right)$. El análisis de distribución espacial de larvas sugirió la tendencia de agregación hacia el sur de la zona de estudio, aproximadamente a $5 \mathrm{~km}$ de la costa. Se encontraron diferencias significativas en la abundancia de ictioplancton entre el sector oriental y occidental de la zona de estudio (Mann-Whitney, $p=0,000062$ ). Sin embargo, no se detectó una relación significativa entre la abundancia de ictioplancton y los valores medios de temperatura (Spearman, $\mathrm{R}=-0,346$ ), salinidad (Spearman, $\mathrm{R}=0,227$ ) y transparencia del agua (Spearman, $\mathrm{R}=0,10$ ).
\end{abstract}

Palabras clave: larvas de peces, taxonomía, distribución espacial, isla Gorgona, Colombia. 
The growing exploitation of fishery resources in the coastal and oceanic waters of the Colombian Pacific has generated an increase in the usage pressure on the fishing areas. This has heightened interest in protected areas such as Gorgona Island National Natural Park and the Malpelo Island Flora and Fauna Sanctuary. Dealing with this situation requires a modification of developmental approaches, that is, making and implementing decisions that integrate conservation, sustainable use, and fair profit sharing without affecting the basic conditions of life and its development (Beltrán \& Ríos, 2000).

Ichthyoplankton studies constitute an important method for evaluating the state of an area's ichthyic stock. Such studies provide information on the composition, diversity, and productive potential of the area, simultaneously allowing the identification of critical zones and periods for the resource's development (Beltrán \& Ríos, 2000). The environmental conditions that affect the larval stages of fish have been widely shown to be decisive elements in the population dynamics; they also structure the ichthyic communities (e.g. Dominici-Arosemena et al., 2000).

The coastal zone of Gorgona Island, located in the Colombian Pacific, is a singularly important protected marine area having strategic ecosystems that are rare in the Eastern Tropical Pacific such as coral reefs and extensive rocky and sandy bottoms (Díaz et al., 2001). Although some studies have been carried out on the existing ichthyic community in this area (Rubio, 1990; Zapata \& Morales, 1997; Zapata, 2001), few have been done on the ichthyoplankton. Most notably, Bernal (2003) described and classified the early stages of fish caught with light traps in a coral reef off Gorgona Island. The objective of the present article, therefore, is to describe the early life stages of the fish caught along the coast of Gorgona Island in September 2005, considering their abundance, spatial distribution patterns, and relationship with temperature, salinity, and water column transparency.

The sampling zone was located between $2^{\circ} 90^{\prime} \mathrm{N}$ $3^{\circ} 06^{\prime} \mathrm{N}$ and $78^{\circ} 24^{\top} \mathrm{W}-78^{\circ} 12^{\top} \mathrm{W}$ (Fig. 1), where the maximum depth is $120 \mathrm{~m}$ (Díaz et al., 2001). The zooplankton was collected with oblique tows from $50 \mathrm{~m}$ to the surface or, at shallow stations, from the bottom $(<50 \mathrm{~m}$ depth); the sampling grid covered 24 stations. A minibongo net $(30 \mathrm{~cm}$ mouth opening; 250 $\mu \mathrm{m}$ mesh) was used to collect the samples; a digital flow meter was attached to the net to estimate the volume of water filtered. All the tows were carried out at 4 knots. Simultaneously, temperature and surface salinity were recorded at each station using a YSI 85 multi parameter probe. The water column transparency was calculated using a Secchi disk and vertical records of temperature and salinity were made with a Seabird-19 CTD unit. The samples were preserved in $10 \%$ buffered formalin in seawater for analysis in the laboratory. Fish larvae were separated from the collected zooplankton and were identified taxonomically according to the meristics and pigmentary characteristics to the lowest possible taxonomic level (family, genus, and/or species), following the identification key of Beltrán-León \& Ríos (2000).

The spatial distribution of fish larvae abundance was evaluated graphically on a logarithmic scale. Larval abundance in the eastern (windward) and western (leeward) zones of the study area were compared using the Mann-Whitney non-parametric test. In order to describe the study area's environmental conditions during sampling, the spatial distribution of temperature and surface salinity as well as the water column transparency were evaluated using the graphic routine for interpolation by kriging. The degree of association between larval abundance and the physico-chemical conditions (temperature, average salinity) in the study area water column were also evaluated using a non-parametric Spearman analysis.

Fish larvae abundances fluctuated between 69 and 16,837 larvae $1000 \mathrm{~m}^{-3}$. The highest abundance was found in the southeastern zone of the study area (Fig. 2). Larval stages of 35 species were identified; these belonged to 14 families (Table 1). The most abundant and frequent families were Gobiidae Lithrypnus sp. (35\%) and Sciaenidae spp. (15\%); Engraulidae, Cetengraulis mysticetus (10\%); Bregmacerotidae, Bregmaceros bathymaster (8\%), and Myctophidae, Myctophum sp. (8\%). The least frequent families were Mugilidae and Carangidae (registered at only one station). Although ichthyoplankton was only collected from $50 \mathrm{~m}$ depth to the surface, the taxonomic analysis included larvae of demersal and deep fish. The sampling, therefore, achieved the goal of incorporating the larvae of pelagic and demersal fish from the study area.

Temperature and surface salinity (Figs. 3a and $3 b)$ were homogenous throughout the sampling zone, although slight variations were recorded (T: 27-27.5 $\left.{ }^{\circ} \mathrm{C}, \mathrm{S}: 29.4-30.2\right)$. However, the water column transparency was highly variable (Fig. 3c), ranging from 7 


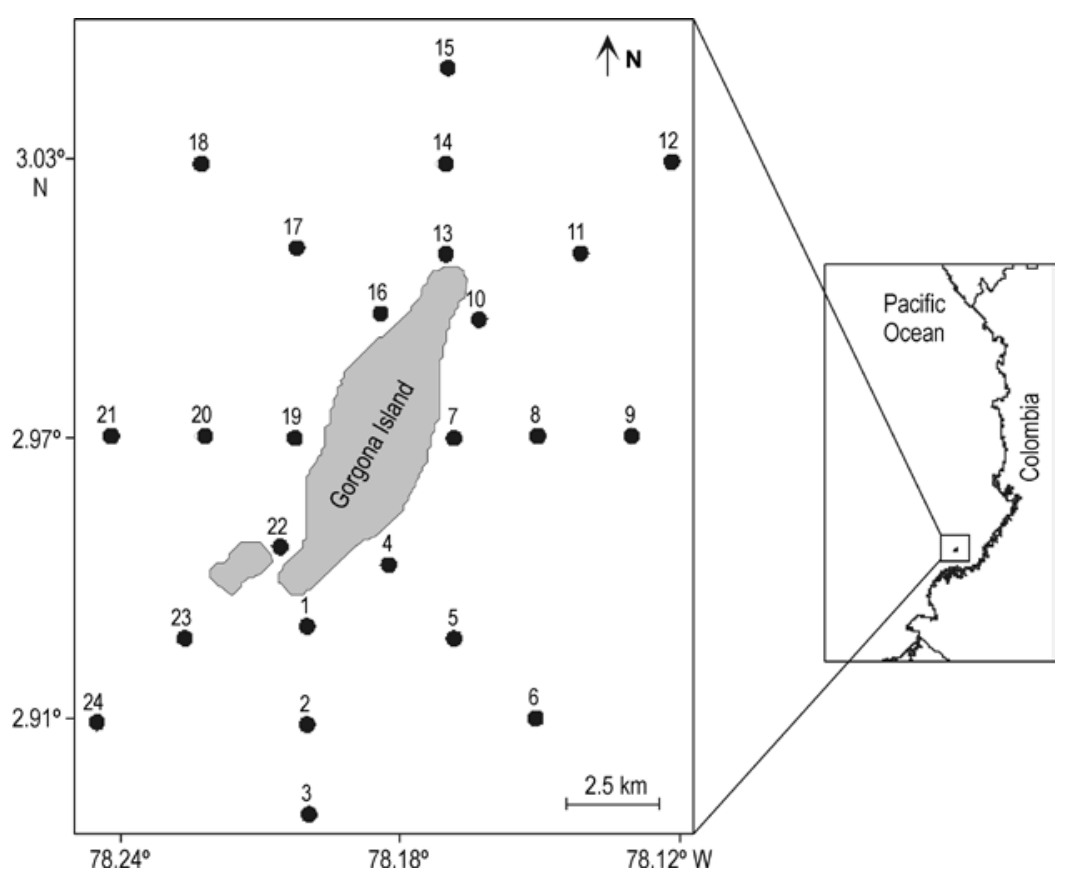

Figure 1. Sampling stations in the coastal influence zone of Parque Nacional Natural Isla Gorgona.

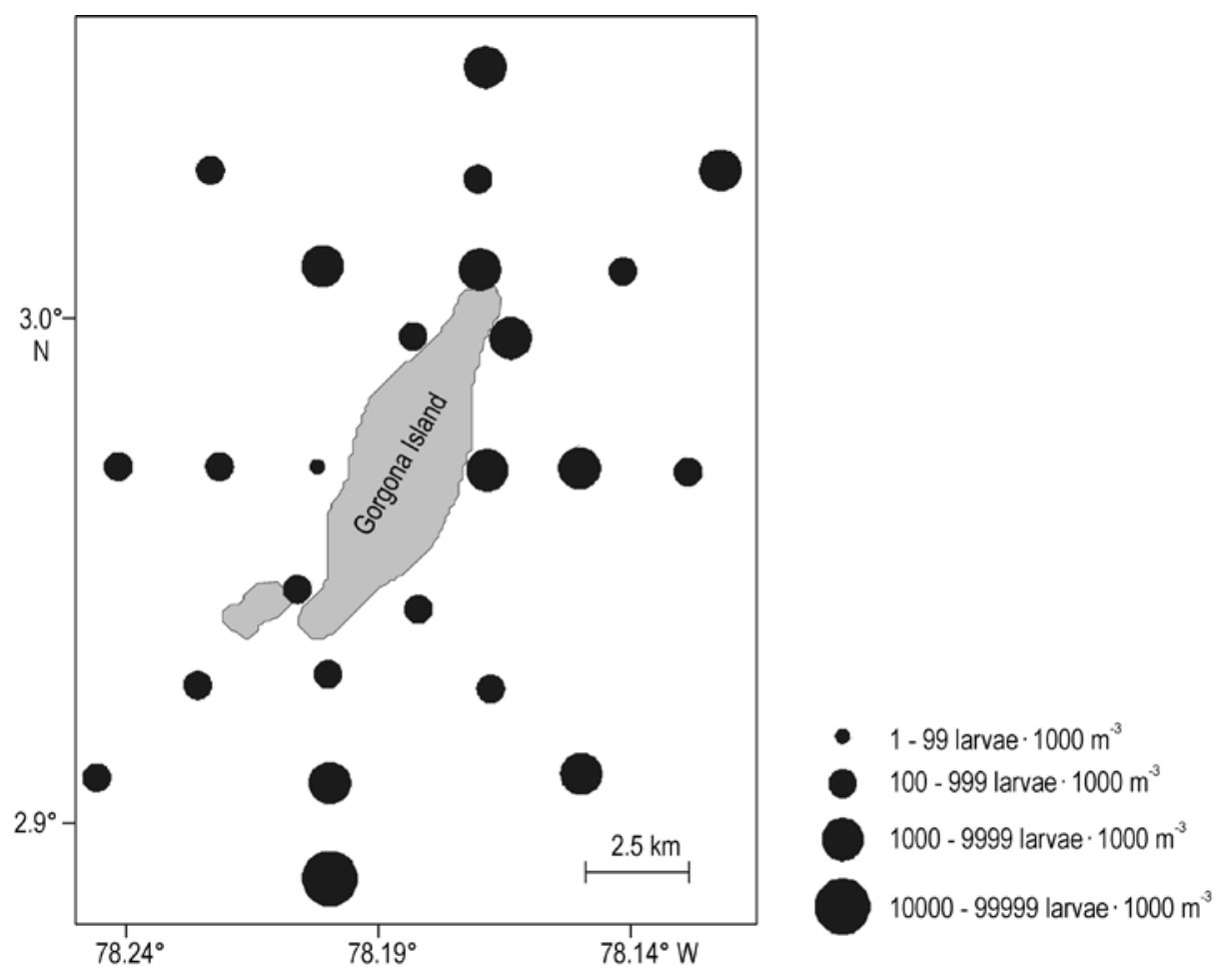

Figure 2. Spatial distribution of fish larvae abundance in coastal influence zone of Parque Nacional Natural Isla Gorgona during September 2005. 
Table 1. Taxonomic list of icthyoplankton from Parque Nacional Natural Isla Gorgona during September 2005.

\begin{tabular}{|c|c|c|}
\hline Family/specie & Mean abundance (larvae $1000 \mathrm{~m}^{-3}$ ) & Composition by family (\%) \\
\hline Gobiidae & & 35 \\
\hline Lythrypnus sp. & 2.130 & \\
\hline Gobiidae sp. 1 & 655 & \\
\hline Gobiidae sp. 2 & 983 & \\
\hline Gobiidae sp. 3 & 492 & \\
\hline Gobiidae sp. 4 & 983 & \\
\hline Gobiidae spp. & 164 & \\
\hline Scianidae & & 15 \\
\hline Scianidae spp. & 1.966 & \\
\hline Larimus sp. 2 & 328 & \\
\hline Engraulidae & & 10 \\
\hline Cetengraulis mysticetus & 1.147 & \\
\hline Bregmacerotidae & & 8 \\
\hline Bregmaceros sp. & 168 & \\
\hline Bregmaceros bathymaster & 1.638 & \\
\hline Myctophidae & & 8 \\
\hline Lampanyctus parvicauda & 492 & \\
\hline Myctophum nitidilium & 164 & \\
\hline Myctophum aurolaternatum & 492 & \\
\hline Benthosema panamensis & 492 & \\
\hline Myctophum sp. & 164 & \\
\hline Lampanyctus sp. & 164 & \\
\hline Symbolophurus evermany & 164 & \\
\hline Ophidiidae & & 6 \\
\hline Ophidiidade sp. & 164 & \\
\hline Lepophidium negropina & 328 & \\
\hline Lepophidium sp. & 1.147 & \\
\hline Trichiurudae & & 3 \\
\hline Trichiurus nitens & 983 & \\
\hline Serranidae & & 3 \\
\hline Diplectrum sp. & 819 & \\
\hline Serranus sp. & 328 & \\
\hline Serranus sp. 2 & 164 & \\
\hline Paralabrax sp. & 164 & \\
\hline Serranus sp. 3 & 164 & 2 \\
\hline \multicolumn{3}{|l|}{ Cynoglossidae } \\
\hline Symphurus sp. & 492 & \\
\hline Paralichthyidae & & 2 \\
\hline Citharichthys sp. & 164 & \\
\hline Citharichthys gilberti & 328 & \\
\hline Citharichthys fragilis & 164 & 2 \\
\hline \multicolumn{3}{|l|}{ Bythitidae } \\
\hline Cataetyx cf. simus & 328 & \\
\hline Gigantactinidae & & 2 \\
\hline Gigantactis sp. & 328 & \\
\hline Mugilidae & & 2 \\
\hline Mugil sp. & 164 & \\
\hline Carangidae & & 2 \\
\hline Seriola sp. & 164 & \\
\hline
\end{tabular}



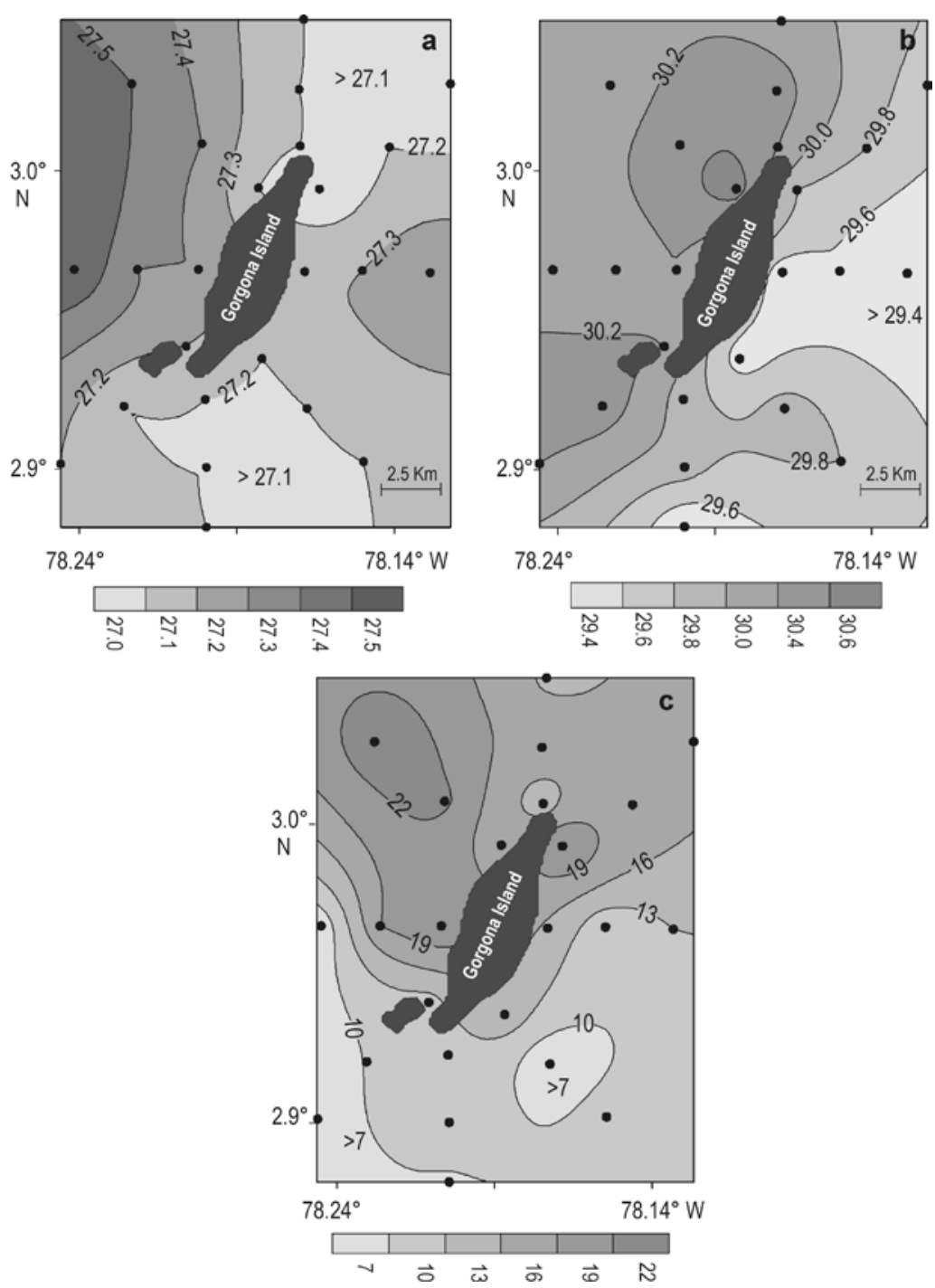

Figure 3. Spatial distribution of parameters sampled in the coastal influence zone of Parque Nacional Natural Isla Gorgona during September 2005. a) temperature, b) salinity, c) transparency.

to $21 \mathrm{~m}$. The thermocline was stable in all the study area. Two layers could be differentiated: a warmer surface layer ( $\mathrm{T}>26^{\circ} \mathrm{C}$ from $40 \mathrm{~m}$ to the surface) and a cooler deep layer $\left(\mathrm{T}<18^{\circ} \mathrm{C}\right.$ below $50 \mathrm{~m}$ deep) (Fig. 4). The vertical salinity distribution varied widely (Fig. 4) due to the presence of numerous freshwater tributaries in the study area and to the effect of the Patía-Sanquianga River plume on the southern area of the island, with subsurface values below 29. Significant differences were detected when the variability in larval abundance was analyzed between the windward and the leeward zones (Mann-Whitney, $\mathrm{p}=$
0.000062). The abundance in the windward zone (to the east of Gorgona Island) was significantly higher. However, no significant relationships were detected between the larval abundance and the physical and chemical variables evaluated (Spearman ${ }_{\text {temperature }} R$ $=-0.346 ;$ Spearman $_{\text {salinity }} R=0.227$; Spearman $_{\text {trans- }}$ parency $\mathrm{P}=0.10$ ).

In general terms, the larval abundance in the study area was high compared to the average abundance values for the Colombian Pacific Ocean Basin (Escarria et al., 2005, 2006). This suggests that the island's coast has significant ecological importance in a re- 


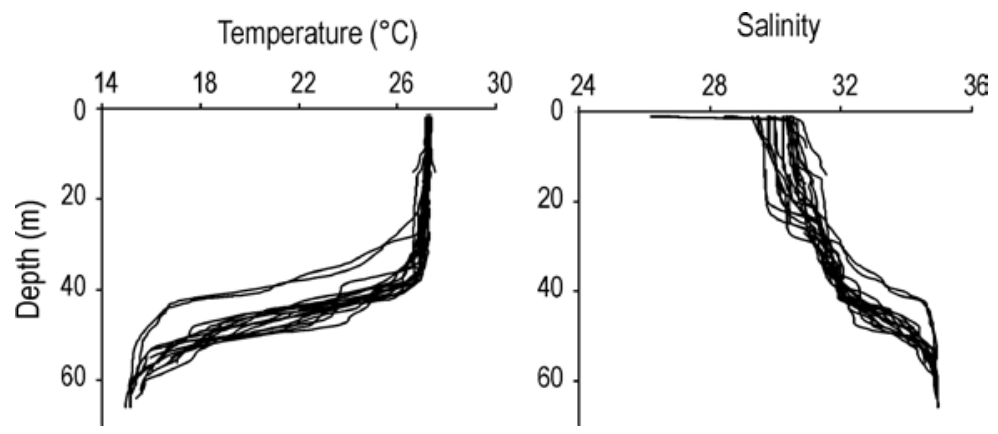

Figure 4. Vertical variation of temperature and salinity in the coastal influence zone of Parque Nacional Natural Isla Gorgona, during September 2005.

gional context. It is likely that the highest abundance on the southeastern side of the island (station 3 ) is associated with local retention processes, the general circulation pattern, and/or the presence of coral and rocky formations in the area. In this zone in particular, the water column is shallow (approximately 12 $\mathrm{m}$ ); thus, the surface effect of the general local wind pattern (southwest wind) produces strong waves that generate a surface drift current toward the island. This increases coastal aggregation processes (E. Rodríguez, pers. comm.). Recently, Giraldo (2006) suggested that the spatial distribution of zooplankton organisms along the coast of Gorgona Island, including ichthyoplankton, is mainly dominated by the local circulation pattern, which generates two marked aggregation cores located in the northwest and southwest sectors of the island, probably as a result of the island's shadow effect.

The mass effect, described by Hammer \& Hauri (1981) for the Great Barrier Reef in Australia, favors the development of high biological productivity in shallow coastal areas such as the south sector of the study area. Moreover, the oceanographic conditions in the study area are regulated by both mesoscale (e.g. annual upwelling in the Panama Bight, the Colombia Current) and local scale processes (e.g. the influence of the continental water discharge plume from the Patía and Sanquianga river complex). The study area is specifically affected by the input of low salinity, high turbidity water from the south (Giraldo $\&$ Zapata, 2006) and high salinity, low turbidity water from the west. Besides, when considering the general wind patterns and local surface circulation described by Díaz et al. (2001), the eastern sector of the study area is characterized by low dynamism, which favors the retention of organisms with poor swimming abilities, for example, fish larvae. This sector of the island is also a suitable spawning area for most marine fish species.

It is important to mention that most of the fish present in the study area were concentrated in the areas where coral reefs develop, mainly on the east side of the island. On the other hand, fish larvae from the families Sciaenidae and Engraulidae are primarily pelagic; the adult specimens of these species, which are of commercial interest, prefer to feed in coastal areas with sandy and muddy bottoms, conditions that are readily available in the area studied herein.

\section{ACKNOWLEDGEMENTS}

Support for this work was provided by COLCIENCIAS-UNIVALLE (243-2004) to A.G. and F.Z. UAESPNN granted access to P.N.N. Isla Gorgona under research permission DTSO-035 to A.G. Anonymous reviewers provided valuable comments on an early version of this manuscript.

\section{REFERENCIAS}

Beltrán-León, B.S. \& R. Ríos. 2000. Estadios tempranos de peces del Pacífico colombiano. Instituto Nacional de Pesca y Acuicultura INPABuenaventura, $727 \mathrm{pp}$.

Bernal-Fuentes, N. 2003. Estadios tempranos de peces capturados con trampa de luz: ensayo preliminar en un arrecife coralino de la isla Gorgona. Tesis de Biología. Facultad de Ciencias. Universidad del Valle. Santiago de Cali, $51 \mathrm{pp}$.

Díaz, J.M., J.H. Pinzón, A.M. Perdomo, 
L.M. Barrios \& M. López-Victoria. 2001. Generalidades. In: L.M. Barrios \& M. LópezVictoria (eds.). Gorgona marina: contribución al conocimiento de una isla única. INVEMAR, Santa Marta, Serie Publicaciones Especiales, 7: 160 pp.

Dominici-Arosemena, A., B. Brugnoli-Olivera, S. Solano-Ulate \& A.R. Ramírez-Coghi. 2000. Ictioplancton de la zona portuaria de Limón, Costa Rica. Rev. Biol. Trop., 48(2-3): 439-442.

Escarria, E., B. Beltrán-León \& A. Giraldo. 2006. Ictioplanton superficial de la cuenca del océano Pacífico colombiano (septiembre 2003). Invest. Mar. Valparaíso, 34(2): 169-173.

Escarria, E., B. Beltrán-León, A. Giraldo \& J. Ortiz. 2005. Composición, distribución y abundancia del ictioplancton en la cuenca del océano Pacífico colombiano durante septiembre de 2003. Boletín Científico CCCP, 12: 23-35.

Giraldo, A. \& F.A. Zapata. 2006. Condiciones oceanográficas y biomasa zooplanctónica en la zona de influencia costera de isla Gorgona: agosto 2005febrero 2006. Proyecto de Investigación "Facto- res físicos, entorno oceanográfico y distribución de arrecifes coralinos en el PNN isla Gorgona". Departamento de Biología, Universidad del Valle, Informe Técnico, 1: $13 \mathrm{pp}$.

Hammer, W.M. \&. R. Hauri. 1981. Effects of island mass: water flow and plankton pattern around a reef in the Great Barrier Reef lagoon, Australia. Limnol. Oceanogr., 26(6): 1084-1102.

Rubio, E. 1990. Ictiofauna Pacífica asociada a los corales de la isla de Gorgona. Rev. Cienc., Universidad del Valle, 2: 97-106.

Zapata, F. 2001. Ecología de peces arrecifales en Gorgona. In: L.M. Barrios \& M. LópezVictoria (eds.). Gorgona marina: contribución al conocimiento de una isla única. INVEMAR, Santa Marta, Serie Publicaciones Especiales, 7: 160 pp.

Zapata, F. \& Y.A. Morales. 1997. Spatial and temporal patterns of fish diversity in a coral reef. at Gorgona Island, Colombia. Proceedings of the $8^{\text {th }}$ International Coral Reef Symposium 1: 10291034 . 